\title{
Mechanized methods for harvesting residual biomass from Mediterranean fruit tree cultivations
}

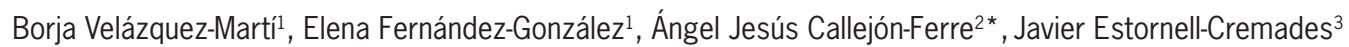

\author{
'Universidad Politécnica de Valencia - Depto. de Ingeniería \\ Rural y Agroalimentaria - Mechanization and Agrarian \\ Technology Division, Camino de Vera, s/n. - 46022 - \\ Valencia - España. \\ ¿Universidad de Almería - Depto. de Ingeniería Rural, Ctra. \\ Sacramento s/n. de La Cañada de San Urbano - 04120 - \\ Almería - España. \\ 3Universidad Politécnica de Valencia - Depto. de \\ Cartografía, Geodesia y Fotorametría. \\ *Corresponding author <acallejo@ual.es>
}

Edited by: José Euclides Stipp Paterniani

Received October 15, 2010

Accepted December 15, 2011
ABSTRACT: This study evaluates the technology and work systems used in order to harvest residual biomass from pruning in the specific conditions of Mediterranean fruit orchards (narrow distances between crop-rows). Harvesting has been divided into several types of operations pruning, biomass alignment between crop tracks, biomass concentration in piles, chipping and bundling - which have been analyzed in five Mediterranean cultivations for three years. Altogether, three types of pruning have been analyzed: Manual, previous mechanical followed by manual, and fully mechanical; Two types of alignment: Manual and mechanical; Three concentration systems: Manual, tractor with a rake and a forwarder; Four chipping work organization systems: chipper driven inside orchard and manually fed by operators, mobile chipper driven inside orchard with pick-up header, mobile chipper fed by means of mechanical crane, chipper mounted on a truck fed by means of mechanical crane, which was working in a fixed position in a border of the plot after wood concentration. Also two bundling organization systems were checked: bundler machine working in a fixed position after wood concentration and working inside the plot driven among the crops. Previous concentration of the materials was the best alternative for their chipping or bundling in the studied conditions. Regression models have been calculated to predict the time of work of machinery and labor for each alternative. These equations were used to implement logistic planning as the Borvemar model, which defines a logistics network for supplying bio-energy systems. Keywords: logistic biomass, pruning, bioenergy

\section{Introduction}

Currently, many logistic models have been developed to determine the best alternative for supplying bioenergy systems, including the Bioloco Model (Biomass Logistics Computer Optimization) and Borvemar Moldel (Velázquez-Martí and Annevelink, 2009; Velázquez-Martí and Fernández-González, 2010) Through purpose-built computer models, either one specific objective can be optimized by linear programming or several heterogeneous objectives can be combined by applying goal programming: maximize profits, minimize costs, minimize greenhouse gas emissions, maximize energy returns, minimize energy use, and maximize energy profit (Permen, 2011). Time and cost of technological options for collecting the biomass are also necessary for planning the logistics (Callejón-Ferre and López-Martínez, 2009) and implement the models. The analysis of the supply chain of biomass can be as shown in Figure 1 (VelázquezMartí et al., 2011a; Velázquez Martí et al., 2011b).

This study evaluates the technical possibilities for collecting residual biomass coming from pruning of Mediterranean fruit trees in order to be used as a source of energy or raw material for the wood industry, achieving an economic complement for the fruit producers and also amortization of the management operations in the frame of a sustainable utilization in the Mediterranean area. Up to now, the biomass produced in these agricultural systems has not been mobilized and used for bioenergy production due to technical problems not yet solved in the harvesting or a lack of information about quantity and quality. This study aims to give a review of the technology and work systems for collecting residual biomass from pruning in the specific conditions of Mediterranean fruit orchards (small plots and narrow distances between croplines). This study will enable optimizing the technology available for mobilizing and using the agricultural biomass residues that has not yet been utilized, and obtaining basic data for logistic studies.

\section{Materials and Methods}

Biomass harvesting is defined as any work that may need to be carried out for collecting wood materials from cultivation fields and transporting to a factory for processing or transformation (Asikainen, 2004; Eriksson and Gustavsson, 2010). This harvesting process is made up of independent operations which have different technological options. The phases in harvesting wood biomass from Mediterranean fruit tree orchards can be synthesized as follows: pruning, biomass alignment between the crop lines or concentration in piles, chipping or bundling. The combination of each technological option for each phase will give us a possible variant to carry out the harvesting. Each phase of wood harvesting was analysed in five types of Mediterranean crops in Spain for two years: Citrus trees, olive trees, vineyards, almond and fruit trees such as peach or apricot.

The evaluation was not made in monetary terms but as regards productivity and resources use: work time per hectare, man or machine. This is due to these quantified resources being invariable for the different systems 


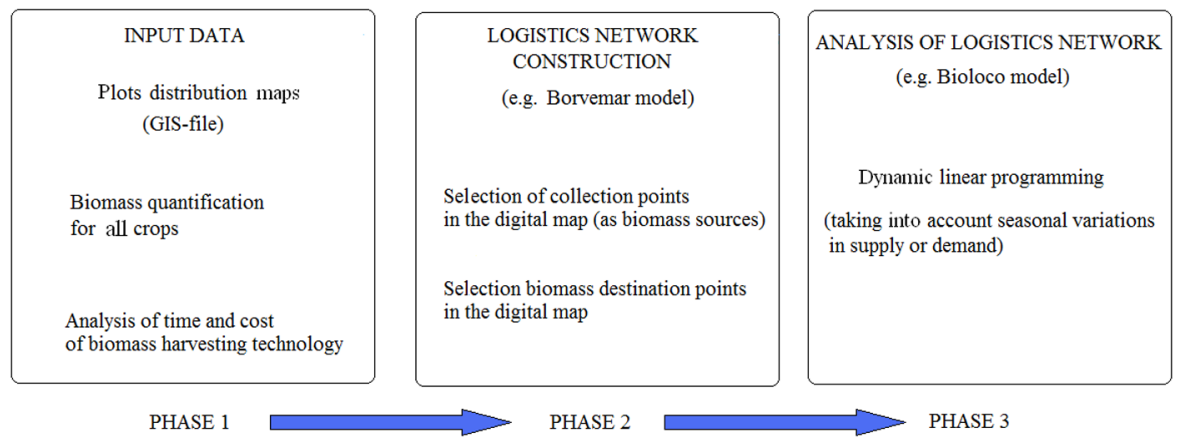

Figure 1 - Phases of the biomass supply chain analysis.

of organization and working conditions, and the economic evaluation may vary according to the evolution of the prices of each of the resources used. The evaluation of resources and productivity is more scientific than the monetary cost (Askew and Holmes, 2001).

\section{Phase 1: Pruning}

We evaluated the time employed by traditionally pruning, which was carried out by hand, either with common utensils such as shears, saws etc. or with a chainsaw depending on the crop. Mechanical pruning was also evaluated. High cost of manual pruning in the plantations of fruit-bearing trees in developed Mediterranean countries (15\% of the total cost in some crops) has led to developing mechanical pruning techniques. Mechanical pruning is defined as the systems that utilize several clutters driven mechanically by a tractor to eliminate part of the branches of a plant with the purpose of improving the production of fruits or giving this a particular shape. The machine used in the pruning trials of consisted on a bar with more or less separated dicks that form an unselective cutting plane.

The unselectively aspect of the mechanized trimming means that this operation is sometimes carried out prior to manual pruning, as a complement. In this case, the mechanical pruning is expected to reduce the time taken to carry out the manual pruning, and therefore to cut down the cost of the operation. In other words, there are three technical options for carrying out the pruning, which have been analyzed in this work: (i) Traditional pruning (manual pruning); (ii) Prior mechanical pruning followed by manual pruning, and (iii)

\section{Only mechanical pruning.}

After pruning, the residual biomass obtained by each system was measured. Bundles of the residual materials were made and weighed by means of a dynamometer. Mass measurement in the field was carried out with moist materials. Five branches of each tree were defoliated and weighed to determine the percentage mass of leaves and wood. Samples of wood were then put into plastic containers to measure moisture content and dry ligneous biomass of all pruned materials. The evolution of the drying process was studied under two types of conditions: open-air drying at an average temperature of $17^{\circ} \mathrm{C}$ and relative humidity of $35 \%$; and stove-dried at $105^{\circ} \mathrm{C}$. Daily measurements of both types were carried out until the weight of the samples was stabilized.

For mechanical pruning evaluation forward speed during the cutting process was measured. This speed was calculated for each track between the crop rows, using a stopwatch to measure the time taken to travel from the beginning of the track until the end. The turning times for changing track were also measured, but they were not used for the speed calculation. Fuel consumed by the tractor was measured by means of a flowmeter installed in the engine. Therefore, an energy balance can be calculated if the calorific power of the biomass obtained is determined where the chips are used as biofuel. Effective time of work was measured including time while the pruning machine moves forward operating, together with the time of turning. Total time of work included the effective time of work and interruptions. The productivity of the machine has been calculated by the equations (1) and (2).

Effective times of work $\left(\mathrm{h} \mathrm{ha}^{-1}\right)=\frac{10000}{\mathrm{~W} \cdot \mathrm{L}} \cdot \mathrm{n} \cdot\left(\frac{\mathrm{L}}{1000 \cdot \mathrm{V}}+\frac{T}{60}\right)$

Total time of work $\left(\mathrm{h} \mathrm{ha}^{-1}\right)=$ Effective Time of work $+I$

Where $\mathrm{W}$ and $\mathrm{L}$ are the width and length of the tracks of the plantation $(\mathrm{m}) ; \mathrm{V}$ is the forward speed of the machine during the phase of work in $\left(\mathrm{km} \mathrm{h}^{-1}\right), \mathrm{n}$ is the number of times the machine goes along each track and $\mathrm{T}$ is the time taken by the machine in turning to change track (minutes), I is the duration of interruptions (h ha-1).

Phase 2: Alignment or concentration of the obtained biomass residues.

After pruning, ligneous residues are generally left spread all over the ground in the field. Processing obliges to carry out their elimination because, if they are not removed, they become an obstacle for the other cultivation operations, and they can be a source of parasites and rot. 
The traditional processing has been burning or grinding on the soil to be able to be quickly degraded and incorporated as organic matter. In order to use the ligneous residues as biomass or raw material, these also have to be collected. Depending on the technology used for removing this residue, it should be aligned between the crop lines or concentrated in piles outside of the field. We have evaluated two types of alignment: Firstly, the alignment carried out manually by operators, and secondly using a mechanical sweeper. A mechanical sweeper is device mounted on the tractor with several rotating disks and/or drums covered in stiff wire bristles or plastic fibres.

The concentration of the materials was evaluated, done manually and mechanically. Two systems for mechanical concentration were analyzed: Using rakes pulled or pushed by tractors, and using a forwarder which load the residual material in a trailer by means of a crane. Altogether, all evaluated technical combinations are shown in the Table 1.

Time of alignment-concentration was measured for each road between the crop lines. When the alignment was carried out manually, two operators picked up the wood materials under the trees and they were left in the middle of the road. This activity was measured with chronometer since the beginning of the road until the end. The rest times between roads were not measured. The ratio of effective work in this operation was calculated by equation 3 . In the trial where a tractor with shovel-rake was used the time of alignment was also measured per road.

Ratio alignment $=\frac{(\text { Time per } \mathrm{road}) \cdot(\text { number of roads per hectare })}{\text { Total time alingment per hectare }}$

For calculating the effective time of work and the total time of work taken by the mechanized rakes the equations (1) and (2) were used. But to calculate the effective time of work and the total time of work taken by the forwader the equations (1) and (4) were used.

Total Time of work $\left(\mathrm{h} \mathrm{ha}^{-1}\right)=$ Effective Time of work $+\mathrm{n}_{\mathrm{d}} \cdot\left(\mathrm{T}_{\mathrm{d}}+\frac{D_{i v}}{V_{d}}\right)+I$

Where $T_{d}$ is the time that the machine takes to discharge the storage container $(\mathrm{h}) ; \mathrm{D}_{\mathrm{iv}}$ is the travelled distance in order to carry out the discharge, including the departure to the concentration point and the return to the point where the chipper should continue the collecting activity $(\mathrm{km}) ; \mathrm{V}_{\mathrm{d}}$ is the displacement speed of the machine $\left(\mathrm{km} \mathrm{h}^{-1}\right)$; I is the time of interruptions $\left(\mathrm{h} \mathrm{ha}^{-1}\right)$ and $\mathrm{n}_{\mathrm{d}}$ is the number of the journey to empty the storage container per hectare.

Table 1 - Possible operations for alignment-concentration.

\begin{tabular}{lcc}
\hline & Alignment & Concentration \\
\cline { 2 - 3 } Option 1 & - & Manual \\
Option 2 & Manual & Mechanized rakes \\
Option 3 & Manual & Fowarder \\
Option 4 & Mechanical sweeper & Mechanized rakes \\
Option 5 & Mechanical sweeper & Fowarder \\
\hline
\end{tabular}

\section{Phase 3: Chipping or Bundling}

Once the alignment or concentration of the residues has been carried out in the plantation, it is necessary to pick up the biomass. The collection and transport require chipping or bundling. These operations have the aim of increasing the bulk density of the materials.

\section{Chipping systems}

Chippers are machines that reduce agricultural or forest residues to very small fragments. Basically, a chipper is comprised of a feed platform by which the material to splinter is inserted in the machine. This material is conducted toward the splinter module by means of the mobile platform and several cylinders. Inside the module, knives or hammers cut and break the material forming small pieces until they can pass through a grid with the desired dimensions. The produced chips are expelled outside by means of a pneumatic flow or by gravity (Asikainen, 1998). Work organization in the residue collection by means of chippers depends mainly on their mobility and feeding systems (Ploj et al., 2006). The evaluated alternatives have been the following:

Harvesting with mobile chippers: These chippers could be driven among cultivation lines, picking up the residues directly on the stand. Three alternatives were evaluated according to its feeding systems: Manually feeding by operators, mechanized feeding by a crane, or using a pick up header.

Chipper with manual feeding: consisted of a hopper where several operators insert the materials while the machine was pulled by an agricultural tractor with very slow velocities. In the trials two operators were manually collecting the residues previously placed in rows, covering the width between crop lines. Small models can be used, which are pushed by the operators, but they have not been evaluated in this work. The evaluated chippers discharged the chipped material by pneumatic flows in a trailer that was pulled behind the chipping equipment.

Chippers with mechanical feeding: Two possibilities were evaluated; machines where the material to chip is collected by a crane; and machines with an axle that raises the material and inserts this into a splinter chamber (pick up header shown in Figure 2).

After the chips are obtained, they are stored in their own bin. Pick up headers require residual materials to be well aligned (Velázquez-Martí and FernándezGonzález, 2009).

\section{The measured parameters were the following:}

Chipper forward speed during the splintering process - It was measured for each road between the crop lines, using chronometer since the beginning of the road until the end. The turnings for changing the road were also measured, but it was not used for the velocity calculation. 

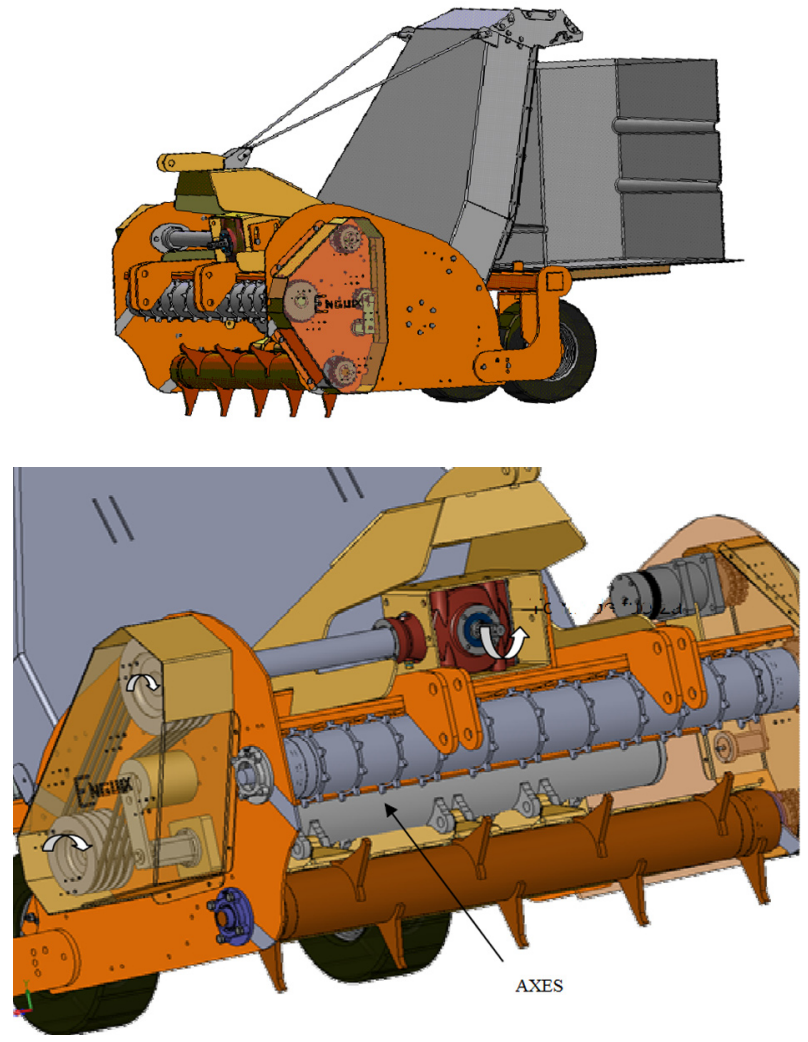

Figure 2 - Machine to remove aligned branches by pick up system.

Sometimes, in the chippers with pick up system, when the branches to be picked up and splintered were very thick, the chipper should go back two or three meters in order to splint correctly the materials and coordinate their insertation in the splintering module. This fact subsidized variable speed in the road. Nevertheless, the average velocity was calculated dividing the distance of the road per the total time used for picking up the aligned materials.

Amount of biomass obtained - This parameter was calculated counting the number of containers of chips emptied in concentration point, together the remainders that had been picked up manually by the two operators. In order to calculate the biomass, a sample of $5000 \mathrm{~cm}^{3}$ of each container was taken. This sample was dried in a stove, and then, it was measured its dry weight and calculated its moisture content. Thus, it was calculated the bulk density of every container and the dried biomass per container.

Fuel consumed by the tractor by means of a caudalimeter inserted in the engine. Therefore, the energy balance can be calculated if the calorific power of the biomass obtained is determined where the chips are used as biofuel.
Effective Time of work - This parameter includes time while the chipper moves forward splintering, together with the time of turning.

Total Time of work - Which includes the effective time of work and the periods of discharge and interruptions. The productivity of the chipper has been calculated by the equation (1) and (4).

Harvesting with transportable chippers: Chippers are machines generally pulled by tractors or mounted on a truck but that work in a border of the plot or in the road next to the plot to carry out the splintering in a fixed position (Asikainen and Pulkkinen, 1998). They cannot be driven inside the stand, before chipping, the material has to be collected and piled outside the plot (Velázquez-Martí, 2006). We evaluated chippers fed by a crane which place the materials in the feed platform. Also the feeding can be carried out by hand, but this option was not evaluated. Because of the tractor that concentrates the residues in the stand carried out different piles separated a variable distances, between 60 and 80 $\mathrm{m}$, the chippers had to go to short distances during the time of work. While grinding, these machines have a continuous discharge system; the produced chips were placed directly in a container by pneumatic drive in order to be transported. The containers were transported to the energy plants by means of trucks.

The time of effective work of these machines was measured by means of chronometer, from beginning to chip the pilled material to it was finished. The total time of work was calculated by the equation 2, where $I$ included the machine displacement between concentration piles.

\section{Bundling systems}

Bundling machines are autonomous equipments for collecting forest or agricultural ligneous remains and use compaction of the materials as work principle. The feed system is carried out by an adapted crane that places the materials in the compression device. After increasing the density the materials are tied by a plastic cord forming cylindrical or prismatic bundle (Johansson et al., 2006; Velázquez-Martí, 2006). The bundles are placed in piles by means of the crane to wait for a conventional truck for transportation. When the transported materials arrive at the factory they can be stored in a reception area until being needed for energy production. The bundles should previously be splintered in static chippers installed in the transformation industries (Dorais, 2007). Two types of the bundling machines were differentiated and evaluated. These are described in the Table 2.

Using bundling machines inside the field was only possible in spaced crops, like olive cultivations. In this case, the bundles are discharged by the machine on the soil without any order and a forwarder must collect and pile the bundles before transport. The most common work system used in fruit tree cultivations is to carry 
out the bundling on the edge of the plot, due to the narrow separation between the rows of trees. In this case, a forwarder collects and piles the materials. A tractor with a rake can also be used. Then, the bundling machine works in a fixed position. Both work systems with bundling machines were evaluated.

Table 3 shows all the technical options evaluated in each phase of wood harvesting in this research. The machinery used in the trials is shown together in the Table 4.

\section{Results and Discussion}

The crop with the highest dispersion (standard deviation) in the biomass produced per tree coming from pruning operations is the olive tree (Table 5). This is because olive trees can be produced with many types of shape and sizes. The orchards evaluated were between 15 and 80 years old. On the other hand, the olive trees are also the crop with highest residual biomass produced. After olive trees, citrus trees come next as regards dispersion.

The time per hectare for the manual pruning, alignment and concentration are closely related with the

Table 2 - Types of bundling machines.

\begin{tabular}{|c|c|c|c|}
\hline & Characteristics & Utilization & Work organization \\
\hline $\begin{array}{l}\text { High } \\
\text { compression } \\
\text { power }\end{array}$ & $\begin{array}{l}\text { 40-70 kW in } \\
\text { compression } \\
\text { system (Trabisa } \\
\text { bundlers) } \\
\text { Large sizes and } \\
\text { weight }\end{array}$ & $\begin{array}{l}\text { They are used } \\
\text { for both pruning } \\
\text { and renewals } \\
\text { operations }\end{array}$ & $\begin{array}{l}\text { They work on the } \\
\text { edge of the field }\end{array}$ \\
\hline $\begin{array}{l}\text { Low } \\
\text { compression } \\
\text { power }\end{array}$ & $\begin{array}{l}20-30 \mathrm{~kW} \text { in } \\
\text { compression } \\
\text { system (Timberjack } \\
1490 \mathrm{D}) \\
\text { Lower sizes and } \\
\text { weight }\end{array}$ & $\begin{array}{l}\text { They are used } \\
\text { only in pruning } \\
\text { operations }\end{array}$ & $\begin{array}{l}\text { They can be used } \\
\text { both inside and } \\
\text { outside the field }\end{array}$ \\
\hline
\end{tabular}

Table 3 - Technical alternative evaluated for each wood harvesting phase.

\begin{tabular}{ll}
\hline Harvesting phase & \multicolumn{1}{c}{ Technical alternative } \\
\hline Pruning & $\begin{array}{l}\text { Traditional pruning (manual pruning) } \\
\text { Previous mechanical pruning followed by manual pruning } \\
\text { Only mechanical pruning }\end{array}$ \\
\hline & $\begin{array}{l}\text { No alignment-manual concentration } \\
\text { Manual alignment and concentration with a pulled rake }\end{array}$ \\
Alignment or & Manual alignment and concentration with a forwarder \\
concentration & $\begin{array}{l}\text { Mechanical alignment with sweeper and concentration } \\
\text { with a pulled rake }\end{array}$ \\
& $\begin{array}{l}\text { Mechanical alignment with sweeper and concentration } \\
\text { with a forwarder }\end{array}$ \\
\hline \multirow{3}{*}{ Chipping } & Mobile chipper manually fed by operators \\
& Mobile chipper with pick-up header \\
& Mobile chipper fed by means of mechanical crane \\
Bundling & Transportable chipper fed by jeans of mechanical crane \\
\hline
\end{tabular}

biomass obtained in the cultivations. These relations are mainly linear equations (Figures 3 and 4). Mechanical pruning is however independent from this parameter.

Table 4 - Models of machinery used in the trials.

\begin{tabular}{|c|c|}
\hline Machine & Model \\
\hline \multicolumn{2}{|l|}{ Mechanical sweeper } \\
\hline $\begin{array}{l}\text { Mobile chipper manually fed by } \\
\text { operators }\end{array}$ & $\begin{array}{l}\text { Caravaggi CIPPO } 251325 \text { T }(50 \mathrm{~kW}) \\
\text { Vermeer BC1000XL Tier } 3(63 \mathrm{~kW}) \\
\text { Ventura TA } 200 \text { TFT ( } 55 \mathrm{~kW})\end{array}$ \\
\hline $\begin{array}{l}\text { Mobile chipper with pick-up } \\
\text { header }\end{array}$ & $\begin{array}{l}\text { Promagri } 2000(48 \mathrm{~kW}) \\
\text { Serrat Olipack } 1800(52 \mathrm{~kW}) \\
\text { Berti Piker } 180(52 \mathrm{~kW}) \\
\text { Jonues Atila Pick-up S } 180(63 \mathrm{~kW})\end{array}$ \\
\hline $\begin{array}{l}\text { Mobile chipper fed by means of } \\
\text { mechanical crane }\end{array}$ & $\begin{array}{l}\text { Junkkari HJ } 260 \text { C (52 kW) } \\
\text { Junkkari HJ 260G*GT (52 kW) } \\
\text { Mus- Max Wood-Terminator 7z (60 kW) } \\
\text { Model TP } 150 / 150 M(50 \mathrm{~kW})\end{array}$ \\
\hline $\begin{array}{l}\text { Transportable chipper fed by } \\
\text { means of mechanical crane }\end{array}$ & $\begin{array}{l}\text { Jenz AZ } 30 \text { D (74.5 kW) } \\
\text { Ventura Wood-Terminator } 7(60 \mathrm{~kW})\end{array}$ \\
\hline Bundler machine & Trabisa Notec ForestPack TC-1. \\
\hline
\end{tabular}

Table 5 - Biomass obtained in pruning operations in the trees evaluated.

\begin{tabular}{|c|c|c|c|c|}
\hline & \multicolumn{2}{|c|}{$\begin{array}{l}\text { Dry biomass } \\
\text { kg per tree }\end{array}$} & \multicolumn{2}{|c|}{$\begin{array}{c}\text { Dry biomass } \\
\text { tha }^{-1}\end{array}$} \\
\hline & Average & $\begin{array}{l}\text { Standard } \\
\text { Deviation }\end{array}$ & Average & $\begin{array}{l}\text { Standard } \\
\text { Deviation }\end{array}$ \\
\hline Orange trees & 8.524 & 3.360 & 4.680 & 1.751 \\
\hline $\begin{array}{l}\text { Mandarine } \\
\text { orange trees }\end{array}$ & 6.500 & 4.405 & 4.338 & 2.725 \\
\hline Olive trees & 22.130 & 7.611 & 4.406 & 3.320 \\
\hline $\begin{array}{l}\text { Vines with vase } \\
\text { shape }\end{array}$ & 1.254 & 0.307 & 2.028 & 0.502 \\
\hline $\begin{array}{l}\text { Vines with } \\
\text { standard trellis }\end{array}$ & 1.291 & 0.459 & 2.736 & 1.071 \\
\hline $\begin{array}{l}\text { Grapes with } \\
\text { standard trellis }\end{array}$ & 1.401 & 0.257 & 3.183 & 0.578 \\
\hline $\begin{array}{l}\text { Grapes with high } \\
\text { trellis (Y-shape) }\end{array}$ & 3.276 & 0.454 & 5.461 & 0.757 \\
\hline $\begin{array}{l}\text { Grapes with } \\
\text { horizontal trellis }\end{array}$ & 7.045 & 0.976 & 7.827 & 1.084 \\
\hline Almond & 8.424 & 4.855 & 1.057 & 0.602 \\
\hline Fruit trees & 7.925 & 3.812 & 3.725 & 1.652 \\
\hline
\end{tabular}

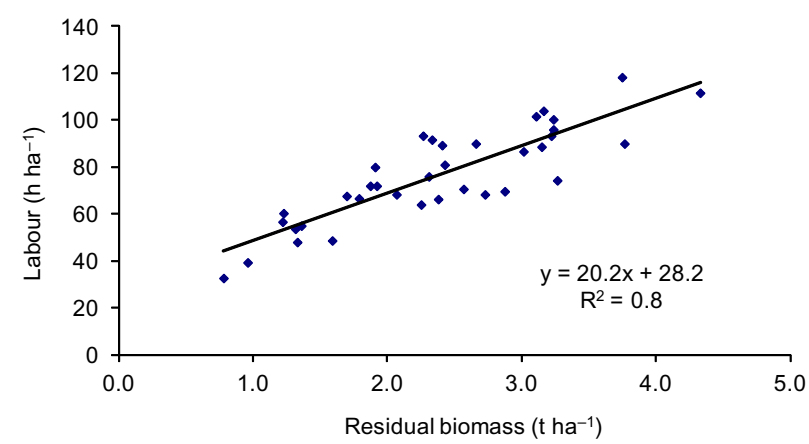

Figure 3 - Time per hectare taken for manual pruning versus residual biomass productivity of the field. 


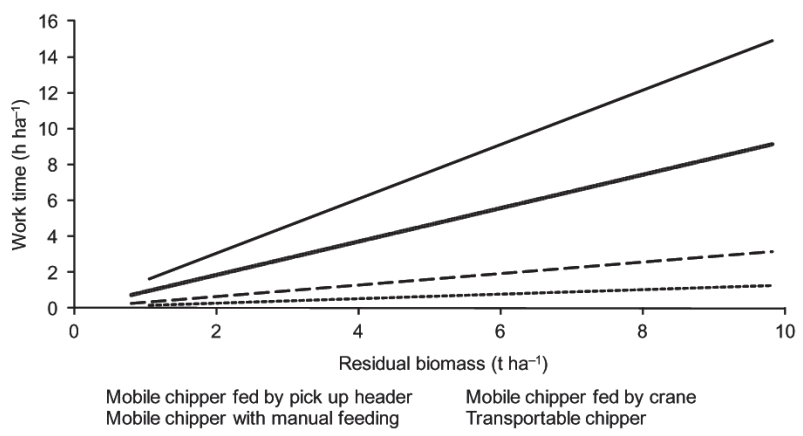

Figure 4 - Time per hectare taken to align and concentrate versus residual biomass productivity of the field.

Table 6 - Work times to carry out the pruning in fruit trees.

\begin{tabular}{|c|c|c|c|c|c|c|}
\hline & \multicolumn{2}{|c|}{$\begin{array}{c}\text { Manual } \\
\text { pruning } \\
\mathrm{h} \text { ha }^{-1}\end{array}$} & \multicolumn{2}{|c|}{$\begin{array}{c}\text { Mechanized } \\
\text { pruning } \\
\mathrm{h} \mathrm{ha}^{-1}\end{array}$} & \multicolumn{2}{|c|}{$\begin{array}{c}\text { Complementary } \\
\text { manual pruning afte } \\
\text { mechanized pruning } \\
\mathrm{h} \mathrm{ha}^{-1}\end{array}$} \\
\hline & Average & $\begin{array}{l}\text { Standard } \\
\text { deviation }\end{array}$ & Average & $\begin{array}{l}\text { Standard } \\
\text { deviation }\end{array}$ & ${ }_{n}^{d}$ Average & $\begin{array}{l}\text { Standard } \\
\text { deviation }\end{array}$ \\
\hline Citrus trees & 10.72 & 0.762 & 2.69 & 0.906 & 7.37 & 0.812 \\
\hline $\begin{array}{l}\text { Mandarine } \\
\text { orange trees }\end{array}$ & 6.71 & 0.600 & 2.68 & 0.819 & 4.61 & 0.640 \\
\hline Olive trees & 23.08 & 1.237 & 3.65 & 1.828 & 19.62 & 1.628 \\
\hline $\begin{array}{l}\text { Vines with } \\
\text { standard trellis }\end{array}$ & s 0.62 & 0.374 & 0.97 & 0.583 & 0.55 & 0.361 \\
\hline Almond & 10.95 & 0.624 & 3.48 & 0.721 & 7.53 & 0.819 \\
\hline Fruit trees & 10.23 & 0.608 & . & . & 7.08 & 0.794 \\
\hline
\end{tabular}

Table 7 - Work times to carry out the alignment of the wood residues coming from fruit tree pruning.

\begin{tabular}{|c|c|c|c|c|}
\hline & \multicolumn{2}{|c|}{$\begin{array}{c}\text { Manual alignment } \\
\mathrm{h} \mathrm{ha}^{-1}\end{array}$} & \multicolumn{2}{|c|}{$\begin{array}{c}\text { Mechanical alignment } \\
\mathrm{h} \mathrm{ha}^{-1}\end{array}$} \\
\hline & Average & $\begin{array}{l}\text { Standard } \\
\text { deviation }\end{array}$ & Average & $\begin{array}{l}\text { Standard } \\
\text { deviation }\end{array}$ \\
\hline Citrus trees & 6.649 & 0.332 & 1,800 & 0.109 \\
\hline $\begin{array}{l}\text { Mandarine } \\
\text { orange trees }\end{array}$ & 6.163 & 0.522 & 1,669 & 0.008 \\
\hline Olive trees & 6.259 & 0.063 & 1,695 & 0.140 \\
\hline $\begin{array}{l}\text { Vineyadrs with } \\
\text { vase shape }\end{array}$ & 2.882 & 0.157 & 0.780 & 0.030 \\
\hline $\begin{array}{l}\text { Vineyadrs with } \\
\text { standard trellis }\end{array}$ & 3.887 & 0.007 & 1.052 & 0.104 \\
\hline $\begin{array}{l}\text { Grapes with } \\
\text { standard trellis }\end{array}$ & 4.526 & 0.387 & 1.226 & 0.066 \\
\hline $\begin{array}{l}\text { Grapes with high } \\
\text { trellis (Y-shape) }\end{array}$ & 7.757 & 0.434 & 2.100 & 0.046 \\
\hline $\begin{array}{l}\text { Grapes with } \\
\text { horizontal trellis }\end{array}$ & 11.119 & 1.045 & 3.011 & 0.188 \\
\hline Almond & 1.502 & 0.035 & 0.407 & 0.004 \\
\hline Fruit trees & 5.292 & 0.499 & 1.433 & 0.136 \\
\hline
\end{tabular}

Table 8 - Work times to carry out the concentration of the wood residues coming from fruit trees pruning.

\begin{tabular}{|c|c|c|c|c|c|c|}
\hline & \multicolumn{2}{|c|}{$\begin{array}{c}\text { Manual } \\
\text { Concentration } \\
\mathrm{h} \mathrm{ha}^{-1}\end{array}$} & \multicolumn{2}{|c|}{$\begin{array}{c}\text { Concentration with } \\
\text { a rake pulled by a } \\
\text { tractor } \\
\mathrm{h} \mathrm{ha}^{-1}\end{array}$} & \multicolumn{2}{|c|}{$\begin{array}{c}\text { Tractor with a } \\
\text { trailer fed by } \\
\text { mechanical crane } \\
\text {-forwarder- } \\
\mathrm{h} \mathrm{ha}^{-1}\end{array}$} \\
\hline & & $\begin{array}{l}\text { Standard } \\
\text { deviation }\end{array}$ & & & Average & $\begin{array}{l}\text { Standard } \\
\text { deviation }\end{array}$ \\
\hline trus & 925 & 0.023 & 356 & 0078 & 1.252 & 0.062 \\
\hline & 2.712 & 4 & 1.257 & 0.019 & 50 & 0.104 \\
\hline Olive trees & 2.134 & 0.126 & 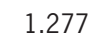 & 72 & 1.178 & 0.073 \\
\hline  & 1.268 & 0.097 & 0.588 & 0.009 & 0.542 & 0.008 \\
\hline & 1.710 & 0.106 & 3 & 0.069 & 0.732 & 0.036 \\
\hline 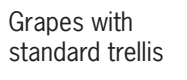 & 1.991 & 0.043 & 3 & 065 & 0.852 & 0.059 \\
\hline $\begin{array}{l}\text { Grape } \\
\text { trellis }\end{array}$ & 3.413 & 0.300 & .582 & 107 & 1.460 & 0.021 \\
\hline $\begin{array}{l}\text { Grapes with } \\
\text { horizontal trellis }\end{array}$ & 4.892 & 0.221 & 0 & 7 & 2. & 0.026 \\
\hline Almond & . & & & & 0.283 & 0.012 \\
\hline Fruit trees & 2.328 & 0.119 & 1.080 & 0.027 & 0.996 & 0.037 \\
\hline
\end{tabular}

Table 9 - Equation selected as predictive models for operation of alignment and concentration.

\begin{tabular}{lcccc}
\hline & Equation & RMSE & $\mathrm{R}^{2}$ & $\begin{array}{c}\text { Significance } \\
\text { P-valor }\end{array}$ \\
\hline $\begin{array}{l}\text { Manual } \\
\text { alignment }\end{array}$ & $W T=1.34 \cdot B+0.43$ & 0.053 & 0.64 & $<0.01$ \\
$\begin{array}{l}\text { Mechanical } \\
\text { alignment }\end{array}$ & $W T=0.73 \cdot B+0.23$ & 0.013 & 0.62 & $<0.01$ \\
$\begin{array}{l}\text { Mechanical } \\
\text { concentration } \\
\begin{array}{l}\text { Manual } \\
\text { concentration }\end{array}\end{array}$ & $W T=0.53 \cdot B+0.06$ & 0.025 & 0.71 & $<0.01$ \\
\hline
\end{tabular}

${ }^{*} \mathrm{WT}$ is the work time of the operation in $\mathrm{h} \mathrm{ha-}{ }^{-1}$; $\mathrm{B}$ is biomass in $\mathrm{kg} \mathrm{ha}^{-1}$.

Averages of work time taken by the three pruning systems evaluated in this research are shown in the Table 6. The time expressed in h.man means that if the operation is carried out by several men (e.g. two or three men), this time per hectare should be divided per this number of operator.

In spite of mechanical pruning taking less time per hectare than manual pruning, an increase of the branches in the interior is detected when the mechanical pruning is done by the external sides of the crown. These branches cause a negative effect in manual harvesting, usually done for citrus trees, vines, grapes and fruit trees. It is also observed that cutting external branches can affect production because some flowers and already jelled fruits have been eliminated. Nevertheless fine cut branches have given rise to a great number of buds. The great majority of these buds are at the bottom of the tree, 
which renews the wood and will develop new productive branches. These are reasons for mechanized pruning not being carried out exclusively, but leading to a complementary manual pruning being done. Consequently, mechanized pruning is only indicated if combined with complementary manual pruning, reducing the economic cost respect on the only manual pruning. This cost can be calculated with the times shown in Table 6 if the price per hour of the operation is known. Tables 7 and 8 specify the productivity of alignment and concentration of the wood residues.

The work time in the manual operations to align or to concentrate the material are more influenced by the available amount of biomass coming from pruning than the mechanized operations (Figure 4). In the Figure 4, it only is shown the tendency line calculated for all experiments for each analysed alternative. In the Table 9 the regression equations, $R M S E, r^{2}$ and significance ( $\mathrm{p}$-valor) are shown. The $\mathrm{r}^{2}$ obtained in the calculations varies between 0.62 and 0.76 . These values mean high variability in the work time. Nevertheless we have considered a good approach for the implementation of the logistics models (borvemar or bioloco).

Time taken for different work organization of chippers used for harvesting of fruit trees pruning residues are shown in Table 10 . They are also lineally re- lated on the amount of residual biomass produced in the plot (Figure 5). In the Table 11 the regression equation, RMSE, $r^{2}$ and significance ( $\mathrm{p}$-valor) are shown. The linear equations calculated had a $\mathrm{r}^{2}$ between 0.67 and 0.79 . In the trials, the chippers with manual feeding employed more time for removing the materials than the other alternatives. Besides, this system uses three operators: the driver and two men for loading the hopper. They are followed by the mobile chippers fed by crane. The reason of this higher time is that the materials to collect for the crane are too thin for a correct feeding; in consequence, a lot of time is sometimes lost picking up the branches. The chipper with pick up header have taken a very acceptable work time per hectare, nevertheless this time has been higher than the time employed by transportable chipper. The reason for this higher time is that these machines have had enough capacity for picking up and chipping the aligned material when the amount of the material in very thick (in olive trees, citrus trees etc.). Because of this fact, they should sometimes go back several meters to repeat the operation at some point where the amount of wood was higher, mainly in olive and citrus residues. The least time for completing the chipping of the amount of biomass removed from a hectare has been taken by the transportable chipper. Their use is nevertheless conditional on the concentration of residues.

Table 10 - Times taken for different work organization of chippers used for harvesting of fruit tree pruning residues.

\begin{tabular}{lcccc}
\hline & \multicolumn{3}{c}{ Mobile chippers } & Transportable chippers \\
\cline { 2 - 4 } & Manual feeding & Feeding by pick up system & Feeding by mechanical crane & Feeding by mechanical crane \\
\cline { 2 - 4 } Citrus trees & 7.092 & 1.827 & 4.208 & 0.608 \\
Mandarine orange trees & 6.574 & 1.130 & 3.901 & 0.563 \\
Olive trees & 7.677 & 1.431 & 3.961 & 0.572 \\
Vines with vase shape & 3.074 & 0.795 & 1.824 & 0.263 \\
Vines with standard trellis & 4.146 & 1.197 & 2.460 & 0.355 \\
Grapes with standard trellis & 4.828 & 1.827 & 2.864 & 0.414 \\
Grapes with high trellis (Y-shape) & 8.274 & 1.941 & 4.909 & 0.709 \\
Grapes with horizontal trellis & 11.860 & 2.032 & 4.037 & 1.017 \\
Almond & 1.602 & 0.513 & 0.951 & 0.137 \\
Fruit trees & 5.645 & 1.053 & 3.349 & 0.484 \\
\hline
\end{tabular}

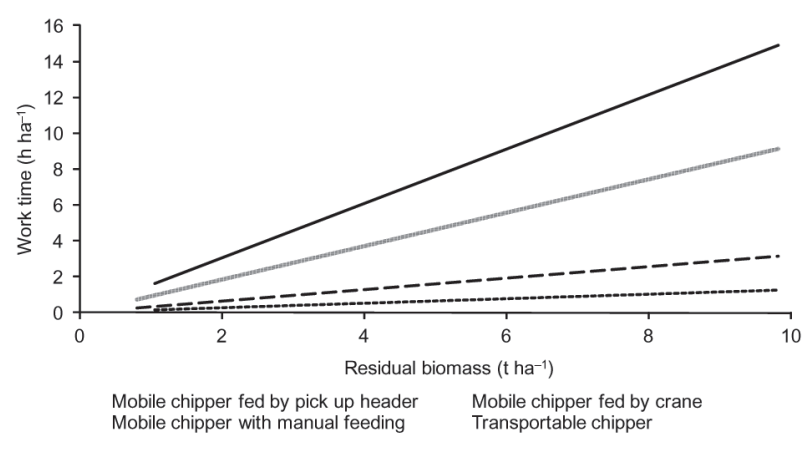

Figure 5 - Work time per hectare taken for chippers versus residual biomass productivity of the field.
Table 11 - Equation selected as predictive models for chipping operation.

\begin{tabular}{lcccc}
\hline & \multicolumn{1}{c}{ Equation } & RMSE & $\mathrm{R}^{2}$ & $\begin{array}{c}\text { Significance } \\
\text { P-valor }\end{array}$ \\
\hline $\begin{array}{l}\text { Mobile chipper } \\
\text { with manual } \\
\text { feeding }\end{array}$ & $W T=1.56 \cdot B+0.02$ & 0.063 & 0.67 & $<0.01$ \\
$\begin{array}{l}\text { Mobile chipper } \\
\text { fed by crane }\end{array}$ & $W T=0.81 \cdot B+0.55$ & 0.043 & 0.69 & $<0.01$ \\
$\begin{array}{l}\text { Mobile chipper } \\
\text { fed by pick up } \\
\text { header }\end{array}$ & $W T=0.21 \cdot B+0.53$ & 0.075 & 0.70 & $<0.01$ \\
$\begin{array}{l}\text { Transportation } \\
\text { chipper }\end{array}$ & $W T=0.13 \cdot B+0.01$ & 0.083 & 0.79 & $<0.01$ \\
\hline *WT is the work time of the operation in $\mathrm{h} \mathrm{ha}^{-1} ; \mathrm{B}$ is biomass in $\mathrm{kg} \mathrm{ha}^{-1}$.
\end{tabular}


The evaluation of the two systems for work by bundling machines is shown in Table 12. The mobile bundler could only be tested in olive and almond fields because the other crops have narrow frame that does not allow big machinery to be driven. The main parameters for predicting the work time adapted to particular conditions of an orchard are presented in the Table 13. Through equation (1), it is possible to calculate the hours per hectare taken if the separation between tree lines is known.

Few researches focused on wood residues harvesting from fruit trees exist, most studies about wood biomass harvesting have been evaluated in forest systems. The results obtained in this research are comparable to those published by Francescato et al. (2007), who work with mobile chippers fed by pick up header in vineyards in standard trellis. They determined a productivity of $1.16 \mathrm{t} \mathrm{h}^{-1}$, obtaining $1.88 \mathrm{t} \mathrm{ha}^{-1}$, and

Table 12 - Evaluation of bundling processing of wood residues coming from fruit tree pruning.

\begin{tabular}{lcc}
\hline & Mobile bundler $^{*}$ & Transportable \\
\cline { 2 - 3 } & \multicolumn{2}{c}{$\mathrm{h} \mathrm{ha}^{-1}$} \\
\cline { 2 - 3 } Citrus trees & - & 4.269 \\
Mandarine orange trees & 1.051 & 3.957 \\
Olive trees & - & 4.019 \\
Vines with vase shape & - & 1.850 \\
Vines with standard trellis & - & 2.496 \\
Grapes with standard trellis & - & 2.906 \\
Grapes with high trellis (Y-shape) & - & 4.981 \\
Grapes with horizontal trellis & 1.374 & 7.139 \\
Almond & - & 0.964 \\
Fruit trees (apricot and peach trees) & - & 3.398 \\
\hline
\end{tabular}

${ }^{*}$ Mobile bundler can be only used in plot with large distances between plants. This condition only occurred in olive and almond trees. For this reason this system could be not tested in the other crops, which have narrow tracks in the evaluated Mediterranean plots.

Table 13 - Characteristics for displacement of the mobile machine used in the trials while they were working.

\begin{tabular}{lcccc}
\hline & $\begin{array}{c}\text { Average } \\
\text { velocity }\end{array}$ & $\begin{array}{c}\text { Turning } \\
\text { Times }\end{array}$ & $\begin{array}{c}\text { Unproductive } \\
\text { times }\end{array}$ & Efficiency \\
\hline $\mathrm{km} \mathrm{h}^{-1}$ & $\mathrm{~h}$ & $\mathrm{~h} \mathrm{ha}^{-1}$ & $\%$ \\
$\begin{array}{l}\text { Mechanized pruning } \\
\text { Mechanical alignment }\end{array}$ & 1.112 & 0.0083 & 0.22 & 92.77 \\
$\begin{array}{l}\text { Concentration with a } \\
\text { rake pulled by a tractor }\end{array}$ & 2.069 & 0.0233 & 0.67 & 83.23 \\
$\begin{array}{l}\text { Concentration with } \\
\text { tractor with a track fed } \\
\text { by mechanical crane }\end{array}$ & 1.837 & 0.0390 & 0.28 & 72.12 \\
$\begin{array}{l}\text { Mobile chipper with } \\
\text { manual feeding }\end{array}$ & 0.315 & 0.0107 & 1.00 & 66.45 \\
$\begin{array}{l}\text { Mobile chipper with } \\
\text { feeding by mechanical } \\
\text { crane }\end{array}$ & 1.540 & 0.0167 & 0.29 & 71.13 \\
$\begin{array}{l}\text { Mobile chipper with } \\
\text { feeding by pick up }\end{array}$ & 1.500 & 0.0500 & 1.44 & 71.12 \\
$\begin{array}{l}\text { header } \\
\text { Mobile bundler }\end{array}$ & 1.146 & 0.1275 & 1.12 & 62.65 \\
\hline
\end{tabular}

therefore $1.5 \mathrm{~h} \mathrm{ha}^{-1}$. Sánchez-Romero and HidalgoMuñiz (2007) analyse two harvesting systems for obtaining olive wood for compost: the mobile chipper with feeding by pick up header and the mobile chipper with manual feeding. They report a productivity of residual biomass coming from pruning between 1.5 and $3.5 \mathrm{t} \mathrm{ha}^{-1}$. The mobile chipper with feeding by pick up header took times slightly higher times in this study, from $1.3 \mathrm{~h} \mathrm{ha}^{-1}$ to $2.3 \mathrm{~h} \mathrm{ha}^{-1}$. The mobile chipper with manual feeding took $4.2 \mathrm{~h} \mathrm{ha}^{-1}$. Wood bundling machines have not been very evaluated in agricultural orchards by the researchers but the work time obtained in this study is comparable to works in forest systems what was determined by Cuchet et al. (2004), Yoshioka et al. (2005) or Johansson et al. (2006), who reported productivities between 2.5 and $5.5 \mathrm{t} \mathrm{h}^{-1}$.

As a conclusion, the resources used in every alternative of the phases for agricultural wood biomass harvesting had high variability. Nevertheless, we consider a good approach for the implementation of the logistics models (borvemar or bioloco). It should be noted that to obtain the monetary cost only is necessary to multiply each resource (time of man's work or machines) by its price.

Regression models have been calculated to estimate the working time used by the machines to harvest residual biomass coming from pruning of fruit trees. The procedure for estimating the working time used by the machines in the biomass harvest is to quantify the amount of residual biomass to collect in the orchard and apply regression models calculated. The amount of available biomass in each crop could be calculated from regression model, such as the models presented by (Velázquez-Martí and Fernández-González, 2009; VelazquezMartí and Fernández-González, 2010) or Velázquez-Martí et al. (2010).

The evaluation of systems for harvesting biomass residues demonstrated that the use of transported chippers is more efficient than mobile chippers, which are driven inside the orchard. A concentration of the pruned materials before the chipping or the bundling gives better results. After this operation, the machines work in a fixed position.

\section{Acknowledgements}

The research shown in this paper was developed by the project AGL2007-62328 funded by the Ministry of Education and Science of Spain, and FEDER funds of European Union

\section{References}

Asikainen, A. 1998. Chipping terminal logistics. Scandinavian Journal of Forest Research 13: 386-392.

Asikainen, A. 2004. Integration of work tasks and supply chains in wood harvesting: cost savings or complex solutions? Journal of Forest Engineering 15: 11-17. 
Asikainen, A.; Pulkkinen, P. 1998. Comminution of logging residues with Evolution 910R chipper, MOHA chipper truck and Morbark 1200 tub grinder. International Journal of Forest Engineering 9: 87-95.

Askew, M.F.; Holmes, C.A. 2001. The potential for biomass and energy crops in agriculture in Europe in land use, policy and rural economy terms. Aspects in Applied Biology 65: 365-374.

Callejón-Ferre, A.J.; López-Martínez, J.A. 2009. Briquettes of plant remains from the greenhouses of Almería (Spain). Spanish Journal of Agricultural Research 7: 525-534.

Cuchet, E.; Roux, P.; Spinelli, R. 2004. Performance of a logging residue bundler in the temperate forests of France. Biomass and Bioenergy 27: 31-39.

Dorais, M. 2007. Organic production of vegetables: stateof the art and challenges. Canadian Journal of Plant Science 87: 1055-1066.

Eriksson, L.; Gustavsson, L. 2010. Comparative analysis of wood chips and bundles: costs, carbon dioxide emissions, dry-matter losses and allergic reactions. Biomass and Bioenergy 34: 82-90.

Francescato, V.; Antonini, E.; Paniz, A. 2007. Energy assessment of the vine shoots in the province of Gorizia. Vitis Energetica 10: 59-69 (in Italian).

Johansson, J.; Lissb, J.E.; Gullberg, T.; Björheden, R. 2006. Transport and handling of forest energy bundles-advantages and problems. Biomass and Bioenergy 30: 334-341.

Permen, T. 2011. Modelling and discrete simulation for the sustainable management of production and logistics issues. Transactions of FAMENA 35: 83-90.

Ploj, A.; Mursec, B.; Cus, F.; Zuperl, U. 2006. Characterization of machines for processing of waste materials. Journal of Materials Processing Technology 175: 338-343.

Sánchez-Romero, A.; Hidalgo-Muñiz, F. 2007. Study on Suitable Machinery for the Work Alperujos Composting. Junta de Andalucia, Sevilla., Spain (in Spanish).
Velázquez-Martí, B. 2006. Harvesting of Forest Residures for Energetic Use. UPV, Valencia, Spain (in Spanish).

Velázquez-Martí, B.; Annevelink E. 2009. GIS application to define biomass collection points as sources for linear programming of delivery networks. Transactions of ASABE 52: 1069-1079.

Velázquez-Martí, B.; Fernández-González, E. 2009. Analysis of the process of biomass harvesting with collectingchippers fed by pick up headers in plantations of olive trees. Biosystems Engineering 104: 184-190.

Velázquez-Martí, B.; Fernandez-Gonzalez, E. 2010. The influence of mechanical pruning in cost reduction, production of fruit, and biomass waste in citrus orchards. Applied Engineering in Agriculture 26: 531-540.

Velázquez-Martí, B.; Fernandez-Gonzalez, E. 2010. Mathematical algorithms to locate factories to transform biomass in bioenergy focused on logistic network construction. Renewable Energy 35: 2136-2142.

Velázquez-Martí, B.; Fernández-González, E.; López-Cortes, I.; Salazar-Hernández, D.M. 2010. Quantification of the residual biomass obtained from pruning of trees in Mediterranean almond groves. Renewable Energy 36: 621-626.

Velázquez-Martí, B.; Fernández-González, E.; López-Cortes, I.; Salazar-Hernández, D.M. 2011a. Quantification of the residual biomass obtained from pruning of vineyards in Mediterranean area. Biomass and Bioenergy 35: 3453-3464.

Velázquez-Martí, B.; Fernández-González, E.; López-Cortes, I.; Salazar-Hernández, D.M. 2011b. Quantification of the residual biomass obtained from pruning of trees in mediterranean olive groves. Biomass and Bioenergy 35: 3208-3217.

Yoshioka, T.; Hirata, S.; Matsumura, Y.; Sakanishi, K. 2005. Woody biomass resources and conversion in Japan: The current situation and projections to 2010 and 2050. Biomass and Bioenergy 29: 336-346. 